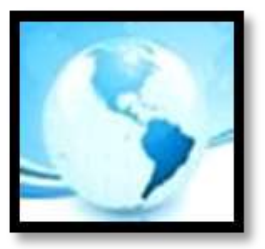

MALAYSIAN ONLINE JOURNAL OF

EDUCATIONAL MANAGEMENT

(MOJEM)

July 2019, VOLUME 7, ISSUE 3, 43 - 63

E-ISSN NO: $2289-4489$

\title{
PERSPECTIVES OF LECTURERS AND STUDENTS ON CLASSROOM MANAGEMENT IN VIETNAM UNIVERSITIES
}

Vu Thi Mai Huong \& Nguyen Thi Thanh Tung

Hanoi National University of

Education, Vietnam.

Corresponding Author:

E-mail:thanhtungsphn@gmail.com 


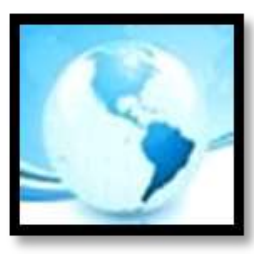

\section{INTRODUCTION}

Nguyen (2009) expressed that the role of lecturer in classroom management relates closely with the autonomy and account ability of universities. Lecturers play many different roles in classroom but one of the indispensable roles is classroom management. Effective teaching and learning cannot take place in a limited classroom management (Robert, Jana, \& Debra, 2013). In contrast, well-managed classes create an environment that promotes teaching and learning. Creating a good learning environment requires a lot of efforts from lecturers, so lecturers need to be aware of and be able to successfully implement the requirements of classroom management.

According to Tang (2014), lecturers are one of the factors that determine the quality as well as the effectiveness of an educational institution or education system of a country. In the current higher education, the role, position, and duties of the lecturer have had fundamental changes. Lecturers not only impart professional knowledge but also teach students how to learn; how to receive and process knowledge; self-training; forming skills, consciousness, professional ethics... to train people with personality and knowledge to meet the requirements of social development.

In Vietnam, universities have been applying the credit system. The autonomy of lecturers is one of the four important rights that the universities are given by the Ministry of Education and Training. With the concept of transferring power from the Ministry of Education to the Universities, the role of the lecturer changes from obeying and abiding to attending in every university issue. Lecturers become partners, decision makers, developers as well as executives, In the school lecturers collaborate to work together, shoulder the school mission, actively participate in all tasks school work, promote teaching and development for the future of the university. In carrying out their role, the instructors are proactive and responsible for teaching activities including classroom management. The Law on higher education of Vietnam (2012) clearly states: Teaching according to the objectives, training programs and fully and qualitatively implementing the training program; Respect the learners' personality, fair treatment with learners, protect legitimate rights and interests of learners; Participate in managing and supervising higher education institutions, participating in Party, unions and other work. Based on problems described, the research questions of this study are: 1) What are the awareness of lecturers and students of classroom management in universities of Vietnam? 2) How does a classroom is managed in universities of Vietnam?

\section{LITERATURE REVIEW}

\section{Definition of Classroom Management}

There are many researches on classroom management. Clandfield and Prodromou (2007) pointed that there are five main areas in classroom management: large classes, discipline, mixed-level classes, homework, teaching exam classes.

Another study found that effective classroom focuses on the aspects: (1) classroom observation; (2) the fluency and attraction in the presentation of the lesson; (3) showing students what their behaviour is expected at certain times; (4) diversity and challenges in assignments for students to performing class (Robert et al., 2013). The author expressed "Classroom observation" is the quick and accurate detection of potential behavioural or behavioural problems and processing it immediately. As a result, the classroom environment can facilitate student learning. Besides, the author also emphasizes that teaching method is also a factor affecting effective classroom management. 


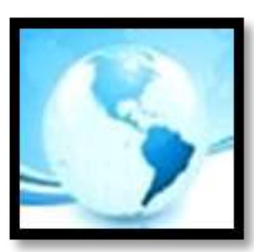

\section{MALAYSIAN ONLINE JOURNAL OF EDUCATIONAL MANAGEMENT (MOJEM)}

In the research of Nguyen (2009), classroom management is the "procedures, strategies and teaching methods that lecturers use to create a classroom environment that encourages learning, as well as building and managing behaviours, learning activities of young individuals and youth groups in that environment. The author considers classroom management to include many different techniques and methods. The changing educational procedures, strategies and flexibility in using teaching methods will lead to creating an environment that encourages student learning or can control the unexpected behaviour of learners affecting the learning atmosphere of the class.

Kohn (2006) supposed that classroom management relate to lecturers who learn to work with students, rather than do things to them - has withstood the test of time and helped educators create positive learning environments that prevent discipline problems from occurring.

Thus, classroom management is a function of lecturers, associated with maintaining students' learning tasks. In order to maintain the learning activities of students, lecturers need to be interested in developing activities programs rules, defining responsibilities, obligations and rights of learners in their own learning (Robert et al., 2013).

Based on the concepts given, it can be said that the classroom management is maintaining the maintaining the students' learning activities by the tasks, techniques, lecturers' different methods used in the classroom. All of these activities towards managing and adjusting learning activities for students. In order to do this, lecturers need to consider building a classroom environment to control student behaviour. Lecturers need to make requests and students need to know what lecturers expect from them through those rules and have behaviours that are in line with lecturers ' expectations (Nguyen, 2009). Overall, classroom management is the act of monitoring and adjusting the classroom atmosphere of the lecturers to support students' learning; minimizing the behaviour (behaviour management) of students that affect the teaching and learning task of other students; and effective use of teaching time.

\section{Content of Classroom Management}

Researchers found that classroom management has three main contents that are recognized by researchers as: Building the classroom environment; Developing regulations and guidelines in classroom teaching and engaging students in classroom management

\section{- Building a classroom environment}

Page (2008) and Tate (2007) express that the classroom environment is the context in which pedagogical activity takes place. This context is created by both the physical environment (tables, chairs, classrooms, learning facilities...) and spiritual values (ideology, customs, aesthetic, moral values...); by time conditions (weather, season, time of day...) as well as psychological space (psychological atmosphere of the class, of the collective); by individual learners (personality characteristics and competence of learners) and teachers (style, pedagogical prestige...) as well as the relationships they establish... Classroom environment can be considered as an ecosystem, in which there is a unity and harmony between teachers and learners, between natural and social conditions, between physical facilities and spiritual conditions of the class.

The environment has a great impact on pedagogical and environmental performance, which can cause psychological pressures, which can stimulate or limit the activities of both lecturers and students (Nguyen, 2009). In classroom management, lecturers must pay attention to both building the physical environment and the psychological environment of the class.

- Building the physical environment of the classroom (Arrangement of classrooms) 


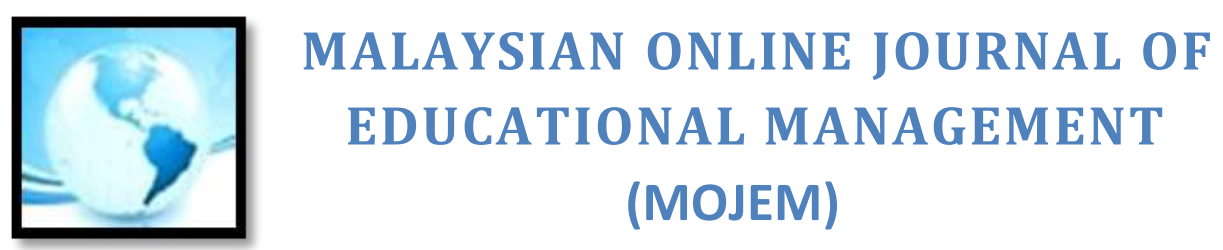

Although a good classroom arrangement is unlikely to guarantee the correct behaviour of students, arranging an unhealthy classroom can create some problems for classroom management. Tate (2007) cultivates a physical classroom environment with the use of lighting, music, humour, constructive conversations, movement, classroom rituals, and parental support to actively engage students in a positive way. Arrangement in the class should focus on:

Vision: Limited vision reduces the excitement and responsibility of learners. In arranging classrooms, lecturers must have a wide range of students at the same time, when teaching lessons to the whole class, when talking to a small group, or for a particular student.

Access: Lecturers must be able to go to any student's seat, especially those who often need help. Lecturers must be convenient when using teaching tools. Learners can easily access necessary learning tools.

Focused attention: When arranging lecturers' seats, be careful to keep students away from influencing factors - for example, lack of concentration students do not sit by the window to avoid looking outside. Detaching and lining up students very well or often have a conflict away from each other to avoid other distracting situations. Class size reduction is one of the most vital and interesting educational problem in the world, especially since it is one of the most expensive choices in educational policy (In \& Jae, 2009).

The purpose of organizing activities: Lecturers must organize a variety of activities in the classroom and streamline it to help lecturers achieve their goals. So, arrangement of classrooms should pay attention to the activities that the lecturer is expected to conduct for the class.

Building the psychological environment of the class: The psychological environment for learning has a close relationship with the psychological atmosphere and educational environment, which includes the type of communication relations, the aesthetics in how to arrange classroom space. Page (2008) paid more attention to creating a safe environment conducive to learning, and building a relationship of trust with your students. The mission of the lecturer is to create a separate psychological atmosphere, a unique culture for our class by keeping the classrooms clean, scientific and maintaining the organization of the class and establishing the departments sincere openness, mutual affection, and knowing for the common on the basis of respect for personal. Burke (2008) expresses the ideal about that educators will learn how to establish a warm classroom climate that fosters a spirit of cooperation, respect, and love for learning while encouraging students to interact courteously with their lecturers and peers. Often, we think that the classroom is a place of teaching and learning, but we must also remember that it is also the place where students experience meaningful emotional moments. That is also the place where social impacts and social skills are formed as well as perfecting the personality. Boynton and Boynton (2007) provide you with a research-based model to help your university: build positive relationships with students, define parameters for acceptable student behaviour, monitor the parameters for acceptable student behaviour, and develop effective consequences when problems occur. Thus, the psychological environment is the space containing the general psychological state of the class in a certain time. This psychological environment is critical to the speed, pace and intensity of students' activities.

\section{Developing Regulations and Guidelines in Classroom Teaching}

The rules and guidelines will be different in each class, but we will not manage classes effectively without them. Simply put, because of the lack of regulations and instructions, teachers cannot manage and teach, and students cannot study well and between them there are no general rules on how to behave. Curwin, Mendler, and Mendler (2008) expanded edition includes new principles for coping with the reality of a teacher's world, including: how to address in-university and out-of-university causes of discipline problems; why to emphasize to students the reasons for your rules; how three internal forces - connection, competence, and control - motivate students to act 


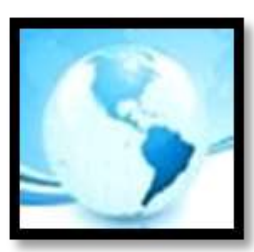

\section{MALAYSIAN ONLINE JOURNAL OF EDUCATIONAL MANAGEMENT (MOJEM)}

inappropriately; the importance of conveying that you respect students' ideas and opinions; and the power you have to reframe problems as positive opportunities (Curwin et al., 2008).

Effective and feasible guidelines allow many different activities to take place in the classroom and still limit confusion and waste of time. Frederick and Catherine (2007) set rules through the tips on: building a support network; communicating and enforcing rules; issuing a mission statement; identifying and dealing with problem students; managing the paperwork; and modernizing your class.

Classroom management also limits inappropriate activities and destructive behaviours so that lecturer saves more time to teach. Payne and Ruby (2006) help lecturers get a handle on the classroom management by handling student bullies, perfectionists, entertainers, and others; respond effectively to the various types of parenting; set rules and guidelines for behaviours and consequences; reduce in appropriate behaviours like harassment, cursing, and threat; and much more (Payne \& Ruby, 2006). Without rules and instructions, lecturers and students will take time to set up order for each class activity. In addition, work habits and annoying behaviour can arise and become difficult to adjust later. Establishing behaviour patterns and habits that create cognitive processes for both lecturers and students and investing to teach these things will benefit the teaching.

\section{Attracting Students to Participate in Classroom Management}

In order to maintain good behaviour of student, lecturers must be flexible in their corporate interventions, types of rewards and discipline in giving psychological students mastery and responsibility for their behaviour. Kohn (2006) reflects on his ideas in the context of today's emphasis on autonomy and accountability and high-stakes testing. The author finds out how his innovative approach - where lectures learn to work with students, rather than do things to and helped educators create positive learning environments that prevent discipline problems from occurring.

The use of interventions must ensure that while teaching hours are interrupted; feelings of discomfort and time and effort are at least reduced. Gossen (2006) help lecturers work with students to help them think about their needs, develop class beliefs, and build strong internal pictures of who they want to be. In order to create such a classroom environment a democratic learning environment is needed. Sapon-Shevin (2010) structured democratic classrooms as models of diversity, cooperation, and inclusion, lecturers can help students learn skills and values that lay a foundation for good citizenship and make a difference in their lives.

Lecturers must make students express their opinions confidently, not hesitate to exchange and interact with lecturers and friends not be afraid of being wrong or being blamed for mistakes. Nash (2009) emphasized the "three Rs" - routines, rules, and relationships. Readers will find guidance on: creating and sustain ing a classroom community that promotes respect and achievement; fully involving students in learning while addressing a wide range of cognitive styles; collaborating with students, colleagues, and parents; and using feedback and assessment to develop professionally and improve students' academic performance (Nash, 2009).

This democratic learning environment gives learners the opportunity to develop intellectually, thoughtprovoking thoughts and views, from which the personality is growing. Bluestein (2008) discusses the impact of stress, brain functioning, learning styles, and social and emotional issues on student behaviour. You'll find examples, guidelines, charts, and anecdotes, along with practical, powerful, and effective ideas to help you: avoid falling into the "rules and punishment" trap; establish win-win authority relationships while defusing conflict and opposition; build a positive, caring, and emotionally safe learning climate; encourage student cooperation, motivation, self-management, and on-task behaviour; and engage even the most defiant, defeated, or resistant learner by using powerful alternative strategies (Bluestein, 2008). In order to create 


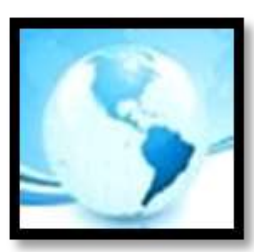

MALAYSIAN ONLINE JOURNAL OF

EDUCATIONAL MANAGEMENT

(MOJEM)

this democratic environment, lecturers need to know how to set good rules and guidelines for their classrooms.

In summary, it can be seen that the three main contents of classroom management enable lecturers to better manage their own teaching activities and student's learning activities (In \& Jae, 2009; Nash, 2009). Content that seems to be unrelated to the content of the lesson has a great influence on whether the lecturer has time or not, as well as a comfortable psychology for his teaching hours. Building a classroom environment with materials helps teachers to gain advantages for their lesson plans and processes (Nash, 2009; Nguyen, 2009). A classroom space where teachers can observe all learners' behaviours as well as their emotions throughout the course of the lecture will help the lecturer not waste time correcting those unexpected behaviour. At the same time, teachers can adjust their own teaching activities through the nuances of learners.

The relationship between lecturers and students is important in building a classroom environment mentally (Payne, 2006; Kohn, 2006). Encouragement and respect for students will help them boldly express their personal views on the problems of the lesson, or it can help students overcome themselves due to timidity own. If a lecturer is enthusiastic in teaching, friendly and willing to help students, students will be comfortable and excited about their study. This will definitely help a livelier lesson and lecturers will also be more interested in their lesson. However, lecturers and student's relationship to achieve educational effectiveness also requires lecturers to maintain a certain control over students.

Building rules and rules of the class is an important job, each subject, each class, each lecturer can give different rules and regulations (Tate, 2007; Curwin et al., 2008). However, the issues raised into regulations will guide all students to follow certain requirements while in the classroom. This will help students stabilize and enter into a discipline where by lecturers do not lose time, or be interrupted by students who are late, interruptions or some disruptive behaviours. Other classroom rules also help students form good habits in the collective environment as well as show their respect for lecturers and classmates.

One of the requirements for lecturers to teach is to encourage students learning spirit but at the same time limit the unwanted behaviours of students that affect the learning atmosphere of the whole class. The commendation and rewarding have great significance in encouraging learners, recognizing the efforts of learners. Since then, it helps each individual to be complimented with a more enthusiastic spirit of learning and at the same time pervasive to other individuals trying to learn. Honouring, rewarding the right people and the right things will create a positive competitive learning environment, so it will be very convenient for the teaching of the lecturers (Bluestein, 2008). Besides rewarding and praising, handling negative behaviours is equally important in creating a positive learning environment. Negative behaviours if bonuses occur will affect the teacher's teaching activities and affect the overall atmosphere of the class. More importantly if undesirable behaviours if not thoroughly treated will be repeated more and more and as such it will break the rules of the class as well as the psychological atmosphere of the class there. At the same time, it causes inhibitions for lecturers that can affect their own teaching work. The three contents of classroom management (Figure 1) are closely related to each other and are a precondition for the preparation of the teacher's lesson content smoothly. To do that requires the lecturer to understand the content of classroom management and value every little thing in it. 


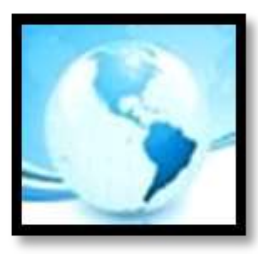

MALAYSIAN ONLINE JOURNAL OF EDUCATIONAL MANAGEMENT (MOJEM)

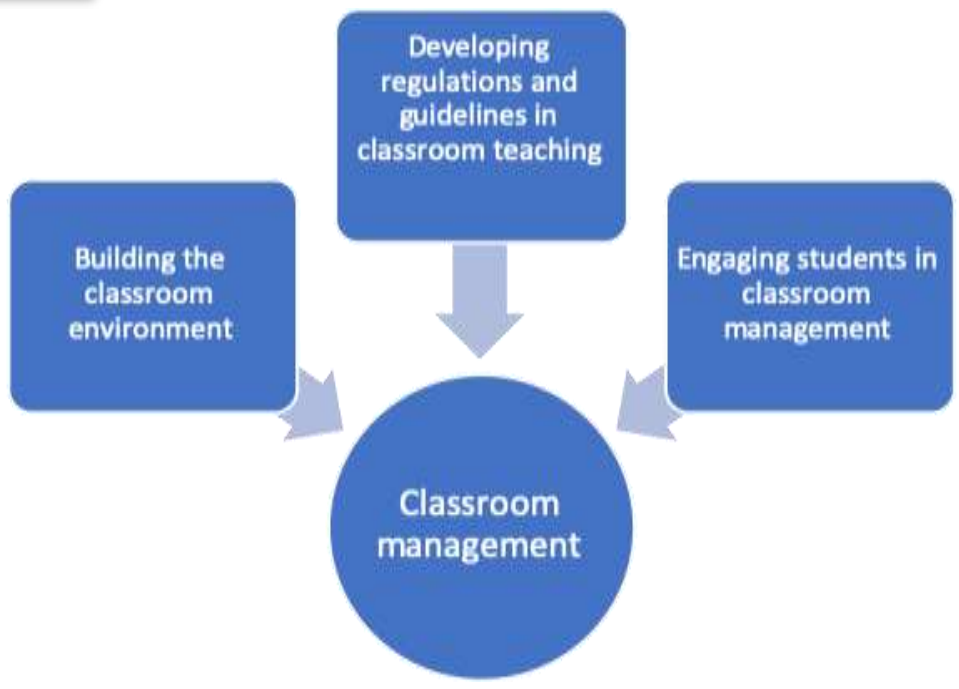

Figure 1: Conceptual framework of the study - three aspects of classroom management

A trend in higher education today is credit-based training with students in many classes and different disciplines can study a subject together. Mastering the requirements of classroom management will help every university lecturer to better manage his or her teaching and student learning. In classroom management, three aspects combine closely to operate learning and teaching of lecturers.

\section{METHOD}

\section{Research Design \& Sampling}

This study aims to show the aspects of classroom management of lecturer. Quantitative method was used to gather information on definition of the issue, three main contents relating to classroom management as: building the classroom environment; developing regulations, guidelines in classroom teaching and engaging students in classroom management.

The population for this study was selected to be from one of the universities in Hanoi, Vietnam with lecturers, students from faculties of social, educational and science. Therefore, a total number of 96 samples of lecturers and students from three different faculties have participated in this study.

\section{Instrument}

A survey questionnaire was used in this study to collect the primary data. The questionnaire was designed based on the study's conceptual framework and the study's three aspects of classroom management that is mentioned earlier. The scale used for collecting data is the Likert Scale. It has three categories of answer namely: Level of evaluation with very necessary, necessary, and unnecessary; Level of implementation with Usually, Sometimes, Never. The instrument was tested at first before being used in research. There were two sections in the questionnaire as below:

- Section 1 - Awareness of the classroom management

For this section, the respondents were ensured that their anonymity and confidentiality of the information are secured. Awareness of the definition of classroom management consisting of four items 


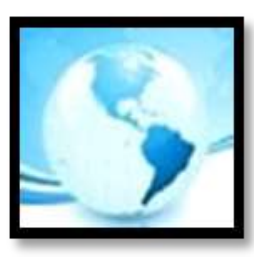

\section{MALAYSIAN ONLINE JOURNAL OF EDUCATIONAL MANAGEMENT (MOJEM)}

on the evaluation of lecturers and students about the importance of the contents of classroom management.

- Section 2 - Situation of implementation of classroom management

For this study, the items of the questionnaire regarding to the issues in classroom management of lecturers. It consists of 15 items for "Establishing classroom environment", 12 items for "Building classroom rules" divided into two part: implementation regulations in classroom rules ( 8 items) and make assessment and develop classroom regulation (4 items), 4 items for "Managing student behaviour".

\section{Validity and Reliability}

Method of internal consistency was utilized in analysing the data from the pilot test to confirm the reliability and validity of each instrument. To test the reliability and validity of the items, Cronbach's alpha test was used. The reliability of the test was calculated with the SPSS 18.0 package software, Cronbach-Alpha method was used on the ground that the test consists of multiple grading questions and the reliability co-efficient of the test was found as $r=0.546-0.949$.Generally, the values suggested that the questionnaire employed for the study had relatively good internal consistency. The value of the Cronbach's Alpha for "Awareness of the classroom management" is at 0.546 for students and 0.74 for lecturers. The value of the Cronbach's Alpha for these 15 items relating to "Establishing classroom environment" is at 0.88 for student and 0.944 for lectures for "Building classroom rules, Cronbach's Alpha is at 0.922 for lecturers and 0.94 for students. In addition, 4 items from "Managing student behaviour" contributed matrix value of Cronbach's Alpha at 0.88 for students while Cronbach's Alpha is at 0.94 for lecturers.

\section{FINDINGS}

\section{Awareness of Classroom Management}

The following is the analysis of the components relating to the awareness of classroom management, based on answering the questionnaire of lecturers and students. The result of quantitative analysis as shows in Figure 1 below indicates that there are four issues regarding classroom management awareness including: 1) Managing classroom environment; 2) Building a classroom environment; 3) Building classroom rules; 4) Managing learners' behaviour.

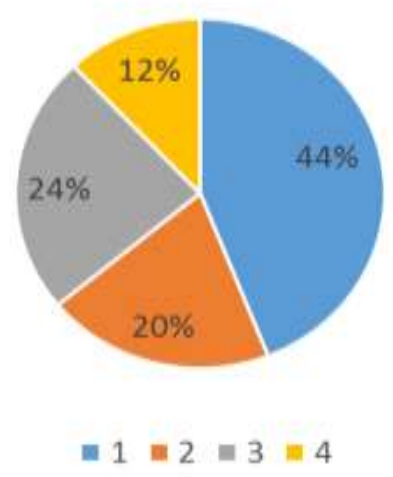

1. Managing classroom environment;

2. Building a classroom environment;

3. Building classroom rules;

4. Managing learners' behaviour

Figure 2. Awareness of lecturers about the definition of classroom management 


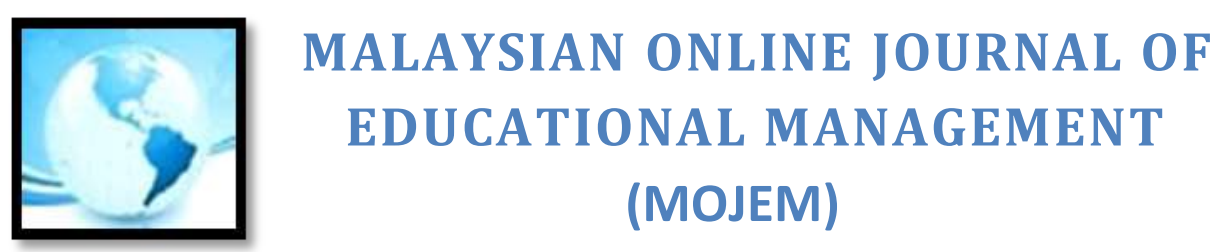

The result in the Figure 2 showed that the number of lectures has high awareness of the definition consisting of $44 \%$. This prove that most of the lecturers surveyed are interested in classroom management activities but have not really understood all the concepts of classroom management as an important function of teaching in the teaching process with its full intents. This is an issue that needs to be overcome in terms of awareness of university and college lecturers because when it is not properly understood in terms of the concept, the process of implementing classroom management of lecturers is difficult to achieve as effectively as desired.

Besides, the research results obtained in Figure 3 below show that there is a big gap in the percentage of students 'perceptions and lecturers' awareness of the concept of classroom management. Most of the surveyed students understand that the lecturers are not only specialized in teaching but also have the function of managing the class to help students perform well their learning tasks with many contents such as: time, space, program of activities, rules, system of responsibility, relations, evaluation and recognition. The full awareness of the function of the lecturer when going to class helps students to know their own interests and coordinate with the lecturers in performing the tasks of learning in class.

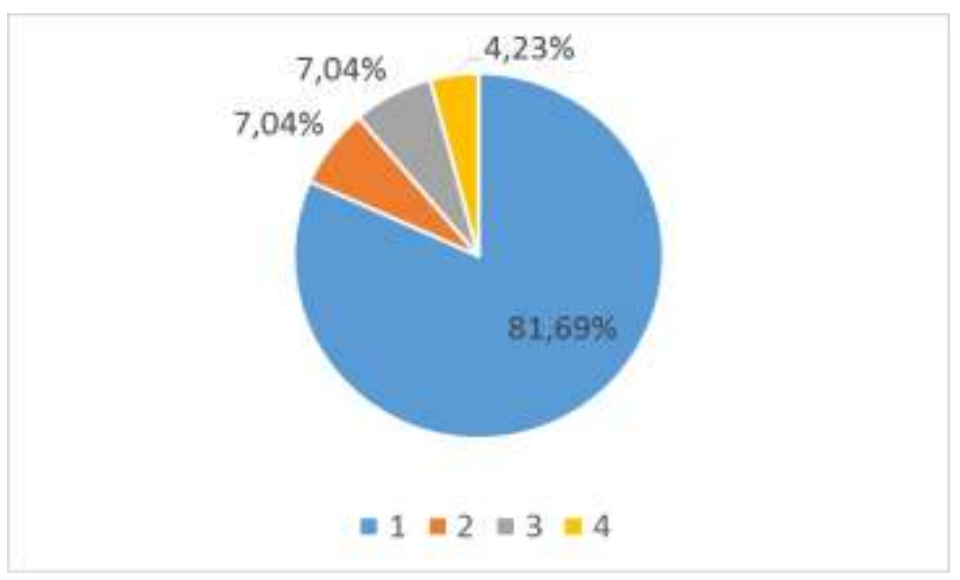

1.Managing classroom environment;

2. Building a classroom environment; 3.Building classroom rules; 4.Managing learners' behaviour

Figure 3. Awareness of students about the definition of classroom management

\section{Situation of Implementation of Classroom Management}

For lecturers, "Building classroom rules" is ranked at the highest rank (Mean $=2.72$ ) and the hierarchy of remaining contents is "Building the classroom environment" (Mean = 2.52), "behaviour of learners "(Mean = 2.28)," Managing classroom environment "(Mean = 2.24).

For students, "Behaviour management of learners" is ranked highest with Mean $=2.46$ and hierarchy of remaining contents is "Building classroom rules" (Mean = 2.37), "Building setting up classroom environment "(Mean = 2.32)," Managing classroom environment "(Mean $=2.17)$. 


\section{MALAYSIAN ONLINE JOURNAL OF EDUCATIONAL MANAGEMENT (MOJEM)}

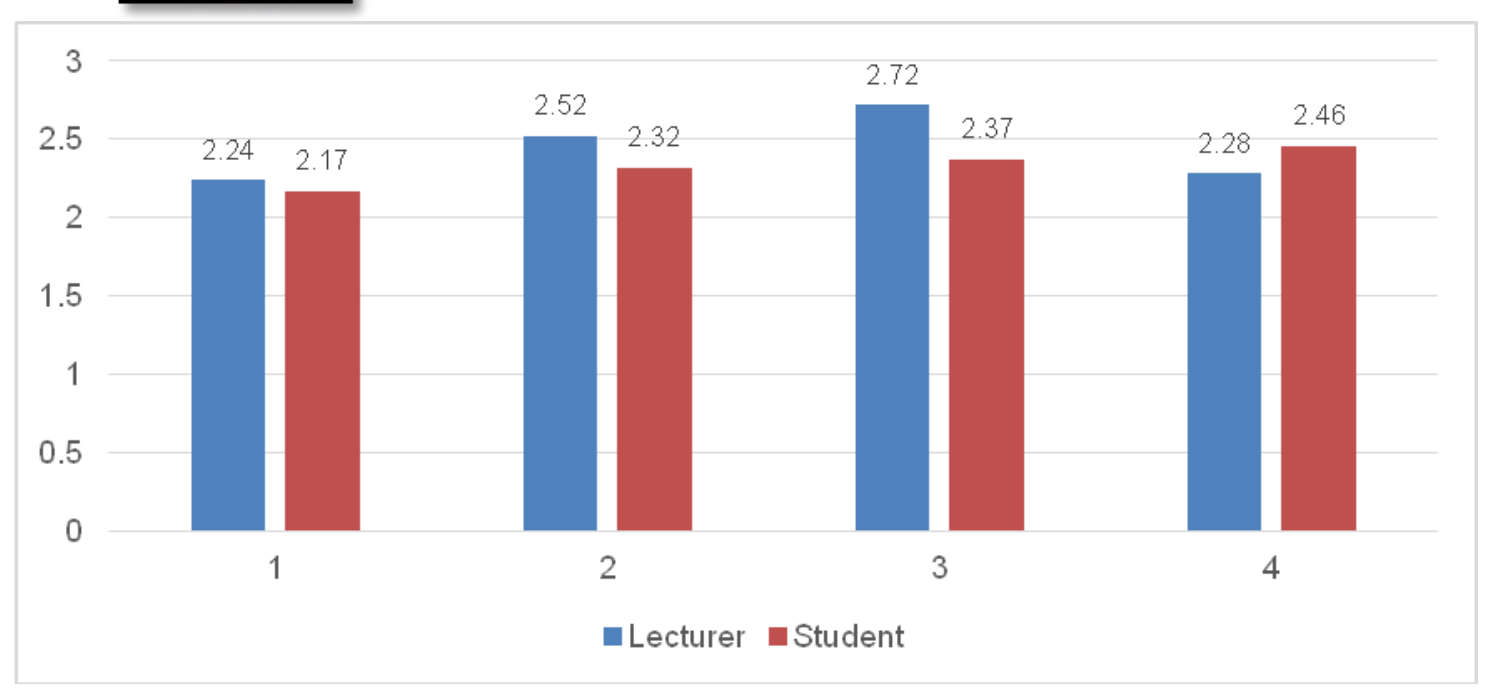

Figure 4. The importance level of the classroom management content

It can be seen that the evaluation of lecturers and students about the importance of the classroom management content is not the same. However, the common point of both survey subjects is to evaluate the content of "Managing the classroom environment" the least important compared to the remaining contents. This shows that three main contents are recognized by researchers as: "Building the classroom environment"; "Building classroom rules" and "Student behaviour management", although having different hierarchies, are generally evaluated by the surveyors as important. Since then, it can be said that both lecturers and students have a certain interest in the content of classroom management.

\section{- Establishing classroom environment}

The Figure 5 below showed the evaluation of lecturers about issue establishing classroom environment. Most lecturers believe that building an open and friendly classroom atmosphere is essential to improve teaching efficiency (GPA = 2.76). Therefore, most lecturers very often perform this work in class $(G P A=2.6)$. In parallel with the building of classroom atmosphere, lecturers also believe that encouraging students to exchange freely, expressing personal views (GPA $=2.68)$ is essential in university teaching, and done with a very regular level $(\mathrm{GPA}=$ 2.48) 


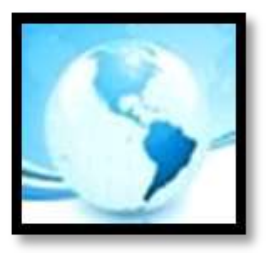

(MOJEM)

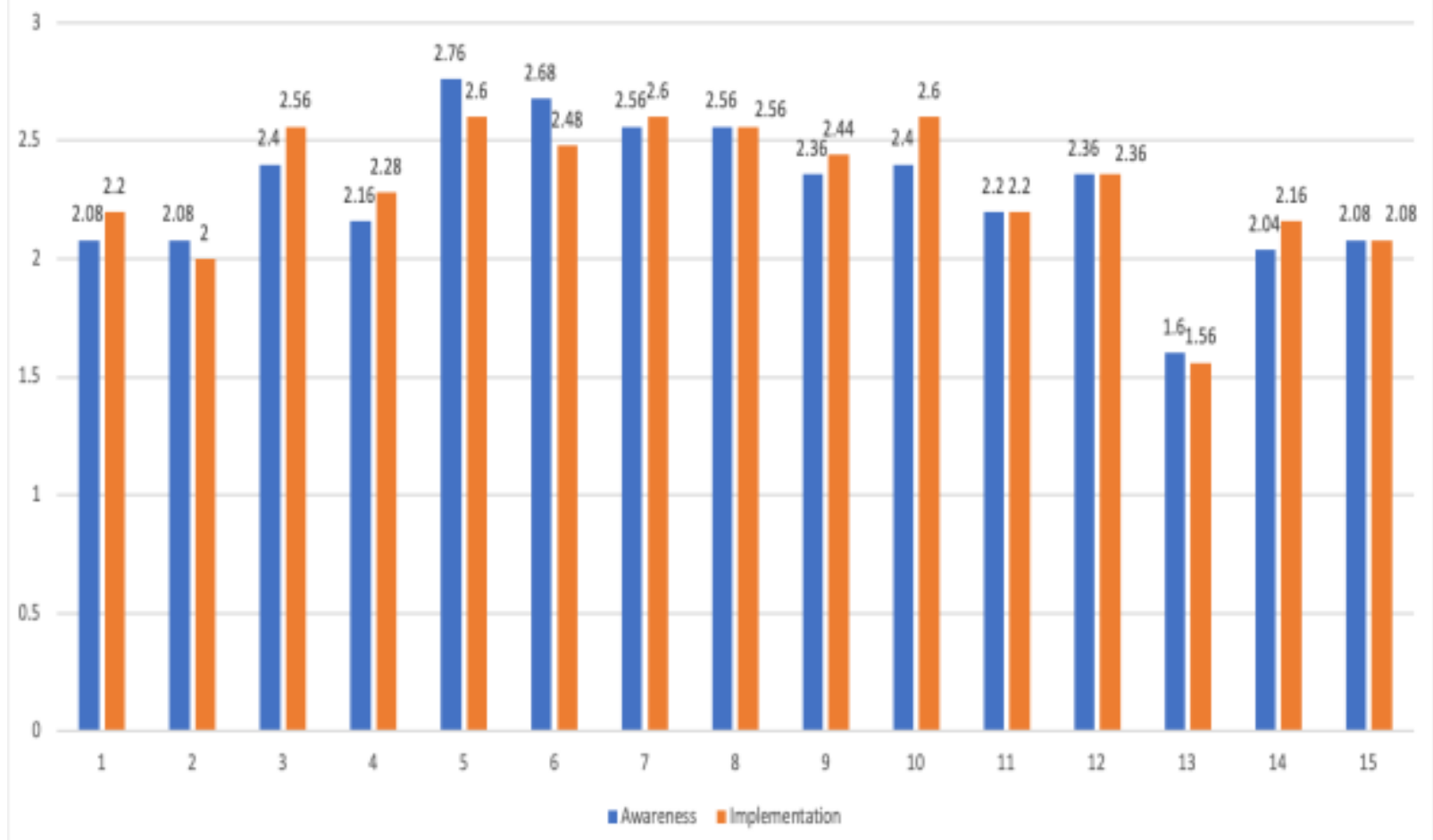

1. Rearrange desks and chairs in accordance with the requirements and progress of the lesson

2. Approach each student during teaching hours

3. Pay attention to the factors affecting student learning (lighting in the classroom, projector, student vision, noise ...)

4. Remind students to build and maintain a clean classroom environment

5. Build an open and friendly classroom atmosphere

6. Encourage students to exchange freely, express their personal views

7. Develop students' confidence

8. Build classroom rules right from the beginning of the new school year

9. Lecturers and students build classroom rules together

10. Building classroom rules ensures fairness for all class members

11. Direct students to take the rules seriously and positively

12. Reward by recognition (giving points, bonus points)

13. Material reward

14. Handling violations by the method of advising penalties

15. Develop a behaviour management profile of some typical cases

Figure 5. Lecturers evaluate and implement the construction of the classroom environment

Most lecturers believe that rearranging desks and chairs is in accordance with the requirements and process of the lesson and also reminds the students to build and maintain a clean classroom environment is not necessary, so implementation also stops only occasionally (Figure 5). Approaching each student during the teaching hours and taking into account the factors affecting student learning (lighting in the classroom, projector, student vision, 


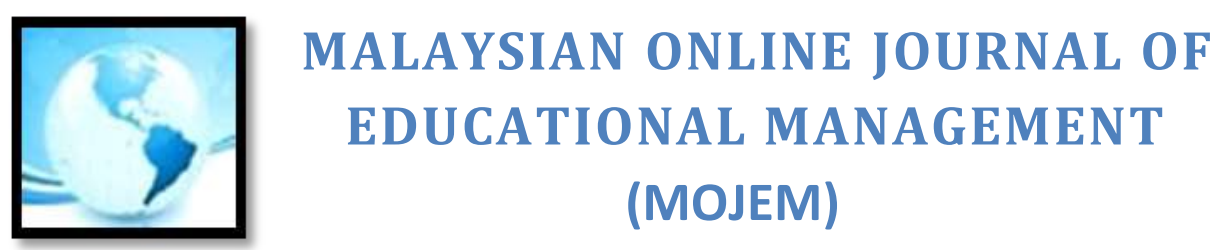

noise, ...), although only being hit The price is at the required level (GPA $=2.08 \sim 2.4$ ) but the implementation level is very frequent (GPA $=2.4 \sim 2.56)$. Thus, it can be said that although the concept and content of classroom management cannot be fully and scientifically proven, most lecturers have formed a habit of building a classroom environment during the teaching process.

Table 1 showed that most students agree that lecturers build an open, friendly classroom atmosphere; encouraging students to exchange freely, expressing their personal views and developing students' confidence is essential in the classroom environment and these contents are conducted regularly by lecturers (59.2\% 66.2\%).

Table 1

Students evaluate and perform tasks during teaching hours

\begin{tabular}{|c|c|c|c|c|c|c|c|c|c|c|c|}
\hline & \multirow[b]{3}{*}{ Items } & \multirow[b]{3}{*}{ 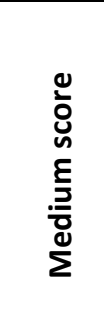 } & \multirow{3}{*}{ 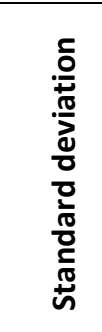 } & \multirow{2}{*}{\multicolumn{3}{|c|}{$\begin{array}{c}\text { Level of evaluation } \\
\%\end{array}$}} & \multirow{3}{*}{$\begin{array}{l}0 \\
\frac{0}{0} \\
\underline{u} \\
\frac{\partial}{3} \\
\frac{D}{0} \\
\sum\end{array}$} & \multirow{3}{*}{ 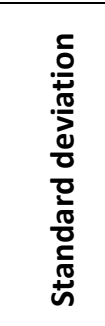 } & \multirow{2}{*}{\multicolumn{3}{|c|}{$\begin{array}{c}\text { Level of evaluation } \\
\%\end{array}$}} \\
\hline & & & & & & & & & & & \\
\hline & & & & 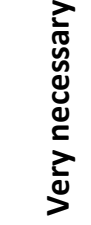 & 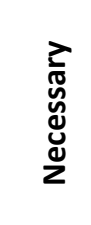 & 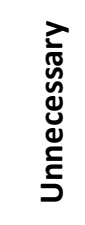 & & & 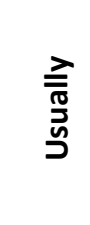 & 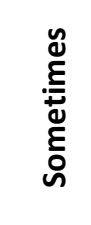 & $\frac{\grave{d}}{2}$ \\
\hline 1 & $\begin{array}{l}\text { Rearrange desks } \\
\text { and chairs in } \\
\text { accordance with } \\
\text { the requirements } \\
\text { and progress of } \\
\text { the lesson }\end{array}$ & 1.971 & 0.459 & 11.3 & 74.6 & 14.1 & 2.323 & 0.550 & 42.3 & 47.9 & 9.9 \\
\hline 2 & $\begin{array}{l}\text { Approach each } \\
\text { student during } \\
\text { teaching hours }\end{array}$ & 2 & 0.615 & 21.1 & 57.7 & 21.1 & 2.253 & 0.502 & 39.4 & 46.5 & 14.1 \\
\hline 3 & $\begin{array}{l}\text { Pay attention to } \\
\text { the factors } \\
\text { affecting student } \\
\text { learning (lighting } \\
\text { in classroom, } \\
\text { projectors, } \\
\text { student vision, } \\
\text { noise,...) }\end{array}$ & 2.154 & 0.462 & 21.1 & 73.2 & 5.6 & 2.493 & 0.441 & 63.4 & 22.5 & 14.1 \\
\hline 4 & $\begin{array}{l}\text { Remind students } \\
\text { to build and } \\
\text { maintain a clean } \\
\text { classroom } \\
\text { environment }\end{array}$ & 2.056 & 0.551 & 19.7 & 66.2 & 14.1 & 2.394 & 0.502 & 50.7 & 38 & 11.3 \\
\hline 5 & $\begin{array}{l}\text { Build an open, } \\
\text { friendly } \\
\text { classroom } \\
\text { atmosphere }\end{array}$ & 2.478 & 0.558 & 53.5 & 40.8 & 5.6 & 2.521 & 0.427 & 66.2 & 19.7 & 14.1 \\
\hline 6 & $\begin{array}{l}\text { Encourage } \\
\text { students to } \\
\text { exchange freely, } \\
\text { express personal } \\
\text { views }\end{array}$ & 2.380 & 0.553 & 43.7 & 50.7 & 5.6 & 2.378 & 0.441 & 59.2 & 29.6 & 11.3 \\
\hline
\end{tabular}




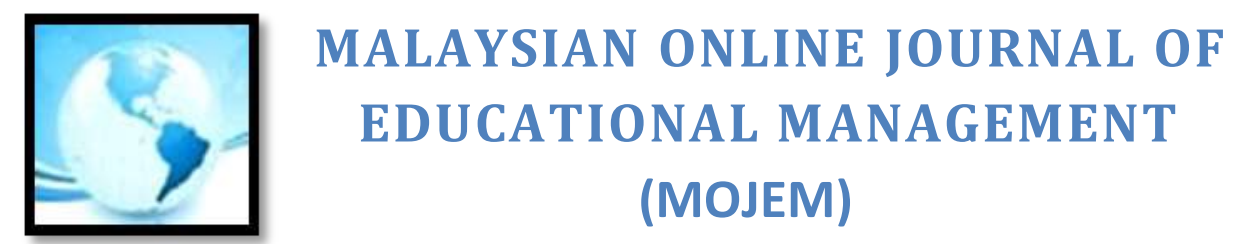

\begin{tabular}{|c|c|c|c|c|c|c|c|c|c|c|c|}
\hline 7 & $\begin{array}{l}\text { Develop students' } \\
\text { confidence }\end{array}$ & 2.549 & 0.498 & 56.3 & 42.3 & 1.4 & 2.521 & 0.411 & 66.2 & 19.7 & 14.1 \\
\hline 8 & $\begin{array}{l}\text { Build classroom } \\
\text { rules right from } \\
\text { the beginning of } \\
\text { the new school } \\
\text { year }\end{array}$ & 2.352 & 0.515 & 38 & 59.2 & 2.8 & 2.352 & 0.464 & 53.5 & 28.2 & 18.3 \\
\hline 9 & $\begin{array}{l}\text { Lecturers and } \\
\text { students build } \\
\text { classroom rules } \\
\text { together }\end{array}$ & 2.323 & 0.513 & 36.6 & 59.2 & 4.2 & 2.267 & 0.482 & 46.5 & 33.8 & 19.7 \\
\hline 10 & $\begin{array}{l}\text { Building } \\
\text { classroom rules } \\
\text { ensures fairness } \\
\text { for all class } \\
\text { members }\end{array}$ & 2.323 & 0.494 & 38 & 56.3 & 5.6 & 2.253 & 0.489 & 45.1 & 35.2 & 19.7 \\
\hline 11 & $\begin{array}{l}\text { Direct students to } \\
\text { take the rules } \\
\text { seriously and } \\
\text { positively }\end{array}$ & 2.211 & 0.553 & 32.4 & 56.3 & 11.3 & 2.211 & 0.592 & 42.3 & 36.6 & 21.1 \\
\hline 12 & $\begin{array}{l}\text { Reward by } \\
\text { recognition } \\
\text { (giving points, } \\
\text { bonus points) } \\
\end{array}$ & 2.309 & 0.525 & 39.4 & 52.1 & 8.5 & 2.323 & 0.502 & 47.9 & 36.6 & 15.5 \\
\hline 13 & Material reward & 1.929 & 0.672 & 21.1 & 50.7 & 28.2 & 1.901 & 0.639 & 22.5 & 45.1 & 32.4 \\
\hline 14 & $\begin{array}{l}\text { Handling } \\
\text { violations by the } \\
\text { method of } \\
\text { advising penalties }\end{array}$ & 2.028 & 0.596 & 21.1 & 60.6 & 18.3 & 2.112 & 0.622 & 36.6 & 38 & 25.4 \\
\hline 15 & $\begin{array}{l}\text { Develop a } \\
\text { behaviour } \\
\text { management } \\
\text { profile of some } \\
\text { typical cases }\end{array}$ & 2.023 & 0.599 & 22.5 & 57.7 & 19.7 & 2.098 & 0.686 & 35.2 & 39.4 & 25.4 \\
\hline
\end{tabular}

- $\quad$ Building classroom rules

The Table 2 below shows that, most lecturers believe that it is necessary (56\%) or necessary (44\%) to build classroom rules from the beginning of the new school year, most lecturers consider this to be a regular task before the commencement. 
Table 2

Lecturers make assessment and develop classroom regulation

\begin{tabular}{|c|c|c|c|c|c|c|c|}
\hline \multirow[b]{3}{*}{ No. } & \multirow[b]{3}{*}{ Items } & \multirow{2}{*}{\multicolumn{3}{|c|}{$\begin{array}{c}\begin{array}{c}\text { Level of } \\
\text { evaluation }\end{array} \\
\%\end{array}$}} & \multirow{2}{*}{\multicolumn{3}{|c|}{$\begin{array}{c}\text { Level of } \\
\text { implementation } \\
\% \\
\end{array}$}} \\
\hline & & & & & & & \\
\hline & & 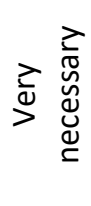 & 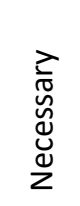 & 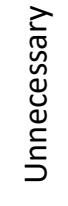 & 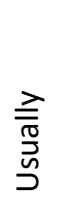 & 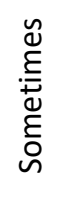 & 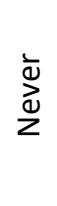 \\
\hline 1 & $\begin{array}{l}\text { Build classroom rules right from the beginning of } \\
\text { the new school year }\end{array}$ & 56 & 44 & 0 & 64 & 28 & 4 \\
\hline 2 & $\begin{array}{l}\text { Lecturers and students build classroom rules } \\
\text { together }\end{array}$ & 40 & 56 & 4 & 56 & 32 & 4 \\
\hline 3 & $\begin{array}{l}\text { Building classroom rules ensures fairness for all } \\
\text { class members }\end{array}$ & 40 & 60 & 0 & 64 & 32 & 0 \\
\hline 4 & $\begin{array}{l}\text { Direct students to take the rules seriously and } \\
\text { positively }\end{array}$ & 24 & 64 & 12 & 32 & 48 & 8 \\
\hline
\end{tabular}

Firstly, teach any subject to students is (64\%). Besides, there is still a proportion of lecturers who occasionally or never build classroom rules right from the beginning of the school year (4\% 28\%). This shows that some lecturers are aware of the necessity of classroom rules but have not yet implemented in the teaching process.

Most lecturers choose to coordinate with students to build classroom rules with a level of regular implementation (64\%) and consider it a necessary job when building classroom rules. After building the rules, instructing students to take the rules seriously and positively is considered necessary by most lecturers (64\%), a lecturer section considers it necessary (24\%); however, not many lecturers perform this task on a regular basis (32\%) and there are still some lecturers who never implement this content (8\%).

In the Figure 6, the construction of classroom rules such as: "Regulations on commenting and building lessons" is the highest ranked by lecturers (GPA = 2.4), "Regulations on posture and behaviour in the hour" and "Regulations on how to treat lecturers and friends" ranked as the last by lecturers (GPA = 1.96). By contrast, the majority of students surveyed also believe that "Regulations on preparation of lessons before class" is necessary $($ GPA $=2.23)$. 


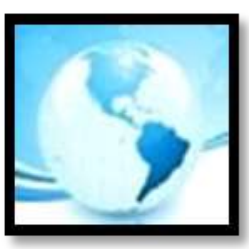

MALAYSIAN ONLINE JOURNAL OF

EDUCATIONAL MANAGEMENT

(MOJEM)

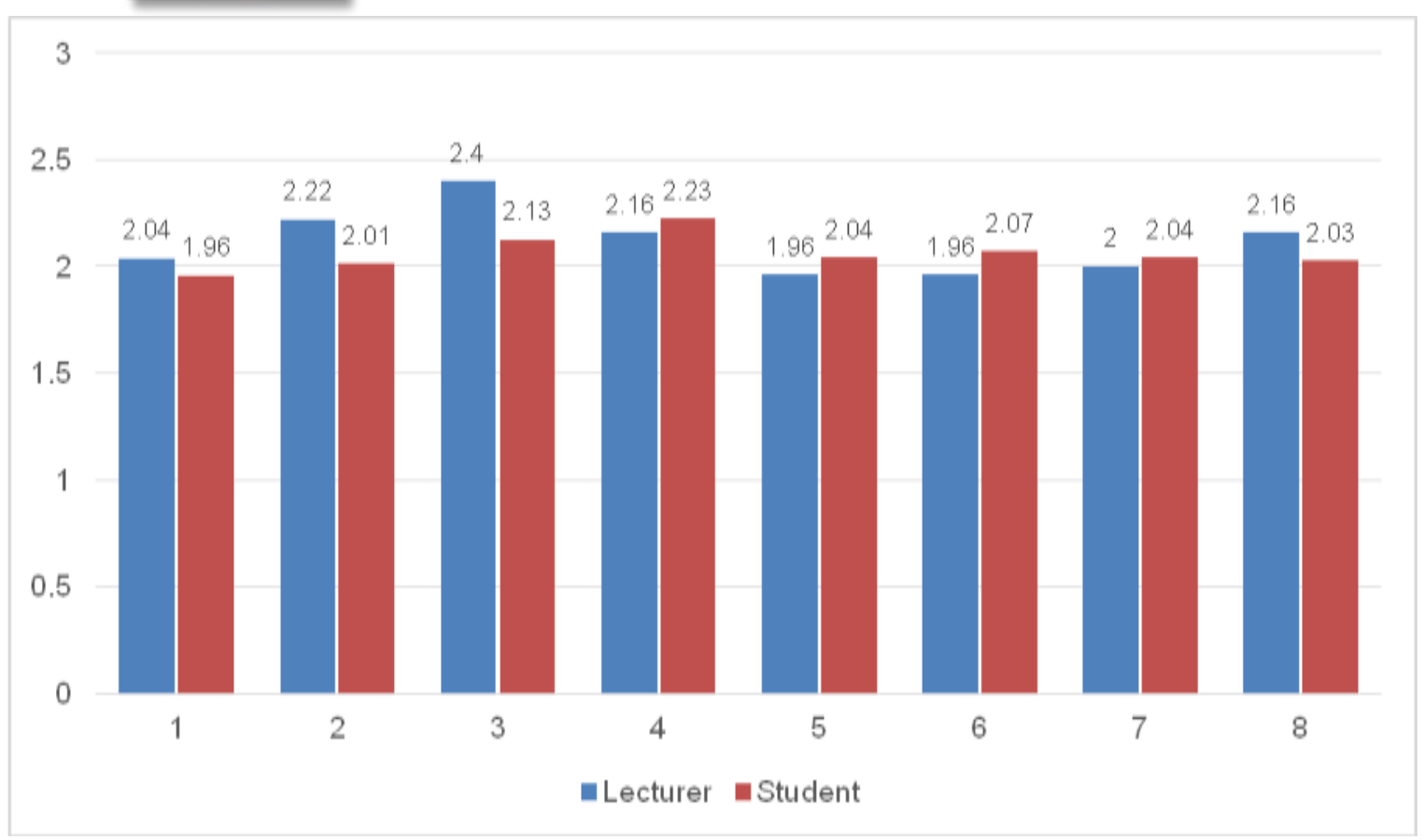
1. Regulations on entry and exit in classrooms
2. Regulations on the use of learning materials and utensils and equipment in classrooms
3. Regulations on commenting and building lessons
4. Regulations on preparation of lessons before class
5. Regulations on posture and behaviour in the hour
6. Regulations on how to treat teachers and friends
7. Regulations on the level of handling of violations and forms of reward
8. Regulations on discussion and debate in classrooms

Figure 6. Assess the appropriateness of the rules in the classroom rules

The level of implementation of regulations related to the teaching and learning process performed by lecturers is more frequent $(52 \% \sim 76 \%)$ are the regulations related to the behaviour and behaviour of students (table 3 ).

Table 3

Lecturers assess the level of implementation regulations in classroom rules

\begin{tabular}{|c|c|c|c|c|c|c|}
\hline \multirow[b]{3}{*}{ No. } & \multirow[b]{3}{*}{ Items } & \multirow[b]{3}{*}{$\begin{array}{l}\text { Medium } \\
\text { score }\end{array}$} & \multirow[b]{3}{*}{$\begin{array}{l}\text { Standard } \\
\text { deviation }\end{array}$} & \multicolumn{3}{|c|}{ Level of application } \\
\hline & & & & & $\%$ & \\
\hline & & & & 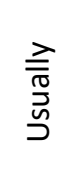 & 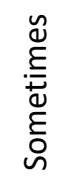 & $\grave{d}_{\bar{d}}^{\bar{d}}$ \\
\hline 1 & $\begin{array}{l}\text { Regulations on entry and exit in } \\
\text { classrooms }\end{array}$ & 2.48 & 0.511 & 52 & 44 & 4 \\
\hline 2 & $\begin{array}{l}\text { Regulations on the use of learning } \\
\text { materials and utensils and } \\
\text { equipment in classrooms }\end{array}$ & 2.48 & 0.511 & 52 & 44 & 4 \\
\hline
\end{tabular}




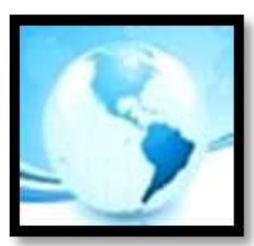

MALAYSIAN ONLINE JOURNAL OF EDUCATIONAL MANAGEMENT (MOJEM)

\begin{tabular}{llccccc}
\hline 3 & $\begin{array}{l}\text { Regulations on commenting and } \\
\text { building lessons }\end{array}$ & 2.68 & 0.538 & 76 & 16 & 8 \\
\hline 4 & $\begin{array}{l}\text { Regulations on preparation of } \\
\text { lessons before class }\end{array}$ & 2.6 & 0.589 & 68 & 24 & 8 \\
\hline 5 & $\begin{array}{l}\text { Regulations on posture and } \\
\text { behaviour in the hour }\end{array}$ & 2.2 & 0.643 & 36 & 48 & 16 \\
\hline 6 & $\begin{array}{l}\text { Regulations on how to treat } \\
\text { teachers and friends }\end{array}$ & 2.32 & 0.679 & 52 & 28 & 20 \\
\hline 7 & $\begin{array}{l}\text { Regulations on the level of } \\
\text { handling of violations and forms of } \\
\text { reward }\end{array}$ & 2.24 & 0.669 & 44 & 36 & 20 \\
\hline 8 & $\begin{array}{l}\text { Regulations on discussion and } \\
\text { debate in classrooms }\end{array}$ & 2.44 & 0.589 & 60 & 24 & 16 \\
\hline
\end{tabular}

The majority of students rated the instructor's performance on regulations higher than the lecturer's selfassessment (see Figure 7). This suggests that in fact, the instructors have put the above provisions into the process of building classroom rules. However, the level of implementation has not been uniform, there is still a large proportion of lecturers who perform at an occasional level or never perform.

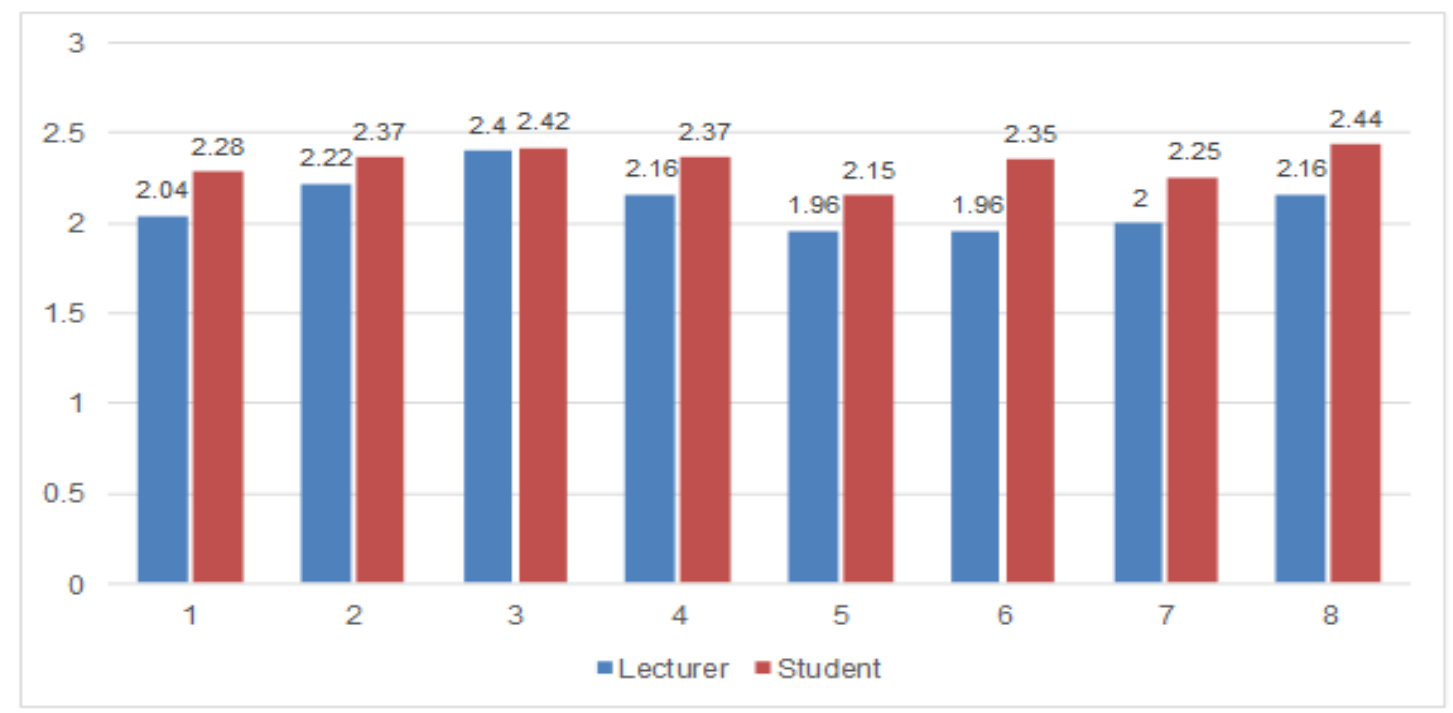

1. Regulations on entry and exit in classrooms

2. Regulations on the use of learning materials and utensils and equipment in classrooms

3. Regulations on commenting and building lessons

4. Regulations on preparation of lessons before class

5. Regulations on posture and behaviour in the hour

6. Regulations on how to treat teachers and friends

7. Regulations on the level of handling of violations and forms of reward

8. Regulations on discussion and debate in classrooms

Figure 7. Assess the level of implementation of regulations in lecturers' classroom rules 


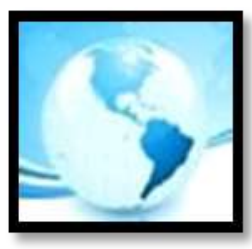

(MOJEM)

\section{Managing Student Behaviour}

There is consistency when lecturers evaluate and implement students' behaviour management (Figure 8). Most lecturers believe that rewarding by recognition (scoring, reward points) is appropriate and effective in managing student behaviour (GPA $=2.36$ ) and therefore, most lectures. The members implement this content more often than the rest $(G P A=2.36)$. The way of rewarding by material is considered unsuitable in managing student behaviour (GPA = 1.6), so only a part of lecturers sometimes does and even lecturers never Do this. Other ways of managing student behaviour such as: Handling violations by the method of sanctioning penalties; Developing a behaviour management profile of some typical cases is also evaluated by a majority of lecturers (GPA $=20.4$ 2.08 ) and implemented at a fairly regular level (GPA). $=2.08 \sim 2.16)$.

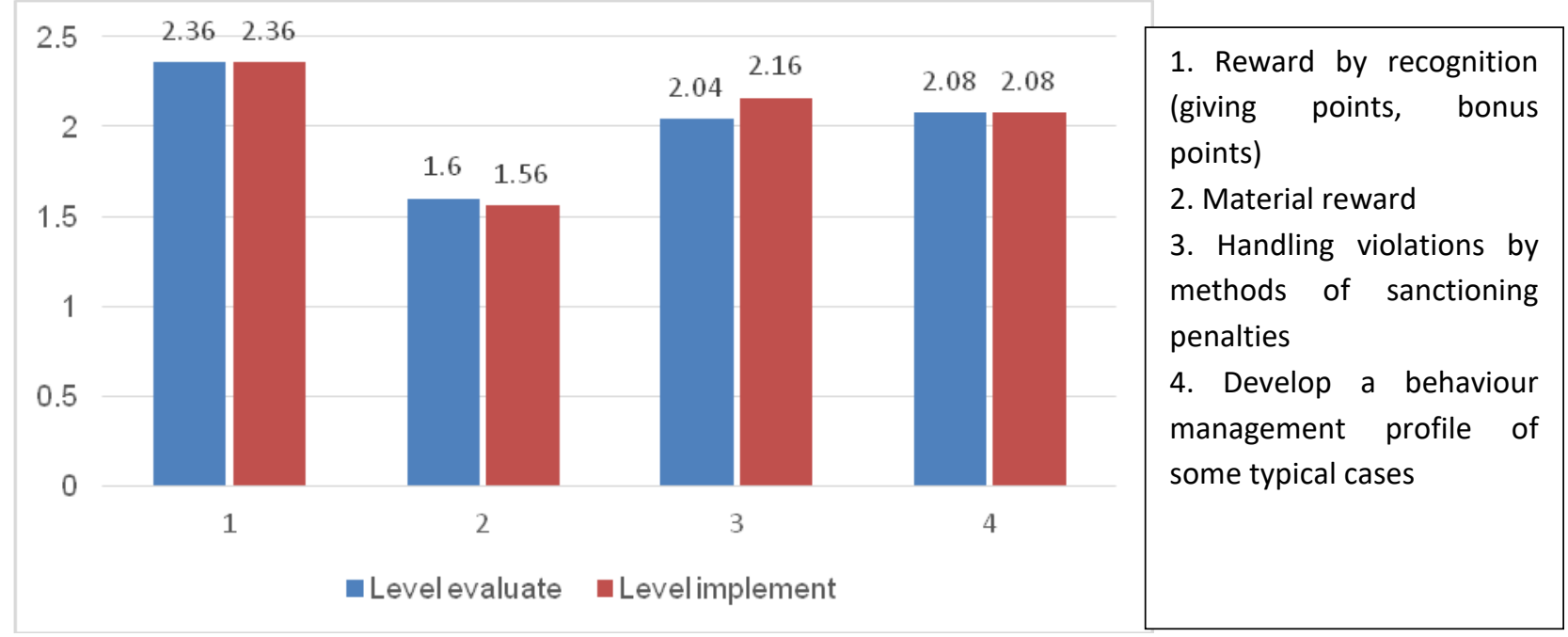

Figure 8. Lecturers evaluate and implement student behaviour management

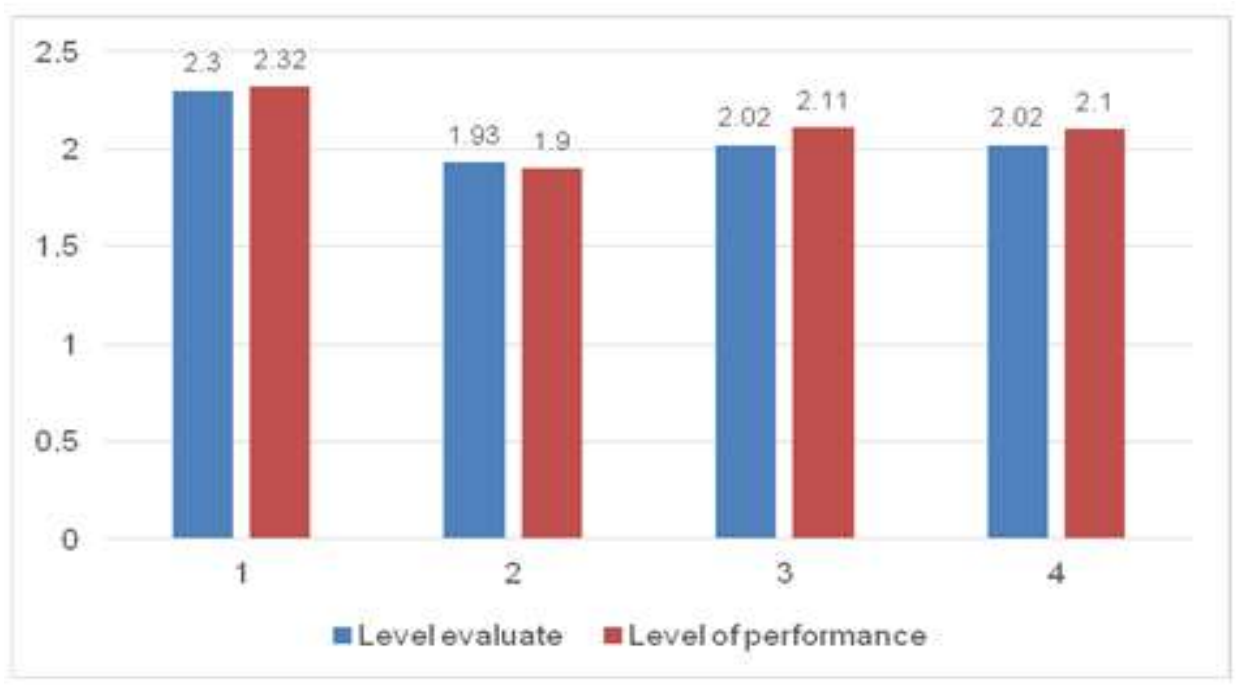

Figure 9. Students assess the appropriateness and level of performance of faculty behaviour management 


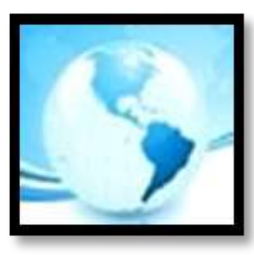

\section{MALAYSIAN ONLINE JOURNAL OF EDUCATIONAL MANAGEMENT (MOJEM)}

The majority of students evaluated the above ways of managing students at an appropriate level (GPA = $1.93 \sim$ 2.3). In particular, the way of rewarding by recognition (scoring, reward points) is ranked the highest in the ways of managing student behaviour (GPA $=2.3$ ) and is performed regularly by lecturers. (GPA = 2.32); the lowest level of material rewarding in the ways of student behaviour management (GPA $=1.93$ ) so most lecturers do not do this.

\section{DISCUSSION}

The concept of classroom management is not a common term in pedagogical training programs. There have been many studies before (Boynton \& Boynton, 2007; Page, 2008; Tate, 2007; Frederick \& Catherine, 2007; Curwin et al., 2008; Nguyen, 2009; In \& Jae, 2009; Robert et al., 2013). However, the survey results show that most lecturers and students have access to the contents of classroom management in the teaching process and in carrying out their learning tasks. Most lecturers surveyed have more or less implemented the content related to building learning environment, building classroom rules and managing student behaviour. However, the level of implementation of the faculty groups is uneven; at the same time, very few lecturers fully implement the contents of classroom management.

Thus, most lecturers and students recognize the importance of classroom management but most pedagogical students do not have enough time to approach and master it before graduation. Learning how to manage classrooms is really a challenge for young lecturers and they only officially face it when they step into the lecture halls. To clarify this issue, go through the question: Please tell me your experience in managing students during class hours, "the author found most of the classroom management experience. The lecturers are all derived from the teaching practice of each lecturer, not a systematic model or regulation in pedagogical environment, and at the same time, "Please share sharing the advantages and difficulties in managing students' learning in the current period ". Most lecturers believe that the pedagogical environment has also educated and trained students about consciousness, lifestyle and calculation. Discipline, the management of student behaviour is also more favourable. There is an effective guiding theory as well as training hours focusing on classroom management skills for lecturers. The ability to manage lecturers' classes has a direct effect on behaviour and performance of students. Students' service affects the quality of the lecturer's own teaching hours. These findings are relevant and are similar to the previous research conducted by Bluestein (2008).

Therefore, the classroom management function is carried out in three basic contents: building a classroom environment, developing guidelines and regulations on classes (classroom rules and student behaviour management as assignments). It can be considered as one of the suggested measures to improve the quality of university teaching, especially in the current industrial age of 4.0. Of course, the content analysed by the author and generalized on the management of classes is just a guiding theory to improve the effectiveness of classroom management as well as the quality of teaching for lecturers (Nguyen, 2009). On that basis, each lecturer will have a specific classroom management plan in each class, each student subject. In addition, to really manage the class well, each lecturer must actively build good relationships with students on the basis of listening and understanding students. Only by understanding the learners would new lecturers know what to do and how to get the most effective teaching hours. It is also the process of lecturers performing their classroom management functions in the most effective way.

The result of the research relating to construction of rules to ensure fairness for class members is also assessed by most students as necessary and implemented by their lecturers quite often. Another relevant study concerning the issue analysis in educational field is the research from Curwin et al. (2008). This is understandable because students are regulated by the rules so they all want that the impact of the rules must bring fairness in adjustment and evaluation. However, the numbers of students who think their lecturers perform at an occasional level or have never implemented level also accounts for a small proportion. This means that the effectiveness of classroom 


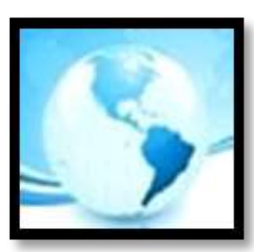

\section{MALAYSIAN ONLINE JOURNAL OF EDUCATIONAL MANAGEMENT (MOJEM)}

management of a faculty is not high, leading to the quality of teaching as not as expected. This is the basis for the author to analyse the causes and propose appropriate adjustment measures.

Regarding regulations in classroom rules, the result of this research found that most lecturers believe that the inclusion of regulations on behaviours related to the lecturer's teaching process and the implementation Student's learning tasks in the classroom rules are appropriate. The surveyed students also agreed with this idea. Regulations on the process of implementing learning tasks such as building lessons; using learning materials and utensils; preparation; Discussing and debating in the classroom are higher than the rankings, reward, and behaviour of lecturers. On the students 'side, the difference in the evaluation between the contents is not much, most of the students think that the regulations mentioned are appropriate to adjust the process of implementing students' learning tasks; however, they rank the rules of posture, behaviour in the hour and how to deal with teachers and friends higher than the lecturer's assessment. This shows that most students are still aware of the importance of moral education in pedagogical environment.

\section{IMPLICATION}

Based on the findings and discussion, the current research draws several implications from both theoretical and practical perspective. In the case of theories, the study contributed to the research on analysing the dimension of classroom management in three aspects: Building the classroom environment; Developing regulations and guidelines in classroom teaching and engaging students in classroom management. Lecturers are able to apply a number of methods to manage their class. In order to become an effective lecturer, each class requires another way to administrate during the class time.

In terms of practical implications, future studies are expected to be able to replicate classroom management analysis in improving career of lecturers effectively. In fact, lecturers at universities pay less attention to management in the class. Some of them only apply one or two in three aspects as express above. The relationship between lecturers and students has been loose.

In order to improve the role of lecturer in classroom management, each one should adapt variety of effectively instruct a large percentage of class including rule, environment establish, student empowerment. However, lecturers have to make the extra effort to improve their teaching and a significant impact on each student. The findings revealed that lecturers' management in class significantly affected the students' attitude and result. This may help the lecturers to revise their role as they could be aware on only teaching in to cooperation with their students to have comfortable environment. In addition, institutions especially the human resource department could take appropriate actions regarding lecturers' training based on the insight given through the research findings. Training or workshop need to provide for the lecturers to build up the personal strategies in terms of enhancing their capacity relating to classroom management to deal with students' characteristics. In addition, conducting training and workshop in employability skills is also important to students since research findings showed a moderate level of students' role in classroom management of lecturers.

\section{CONCLUSION}

For students, attitudes and behaviours alongside solving problems related to the learner's behaviour have greatly influenced the emotions and learning attitude of students. Therefore, the content of "Learner behaviour management" is ranked as the most important by them. This is also an important basis for the author to discuss and propose reasonable measures to improve the effectiveness of classroom management of lecturers. On one hand, both lecturers and students assess the content of building the classroom spirit environment as very necessary and is implemented more often than the content of building the physical environment. This comes from two basic reasons: First, for any subject or any time, the atmosphere of the class always has a great influence on the teaching of the faculty and the process perform students' learning tasks during the promotion process. 


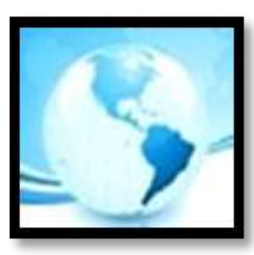

\section{MALAYSIAN ONLINE JOURNAL OF EDUCATIONAL MANAGEMENT (MOJEM)}

Secondly, the construction of the classroom spirit environment does not depend too much on the physical conditions, so lecturers can implement it more frequently and more easily.

On the other hand, it can be seen that the construction of classroom rules, although necessary, is not implemented well. The process of implementing and instructing students to implement them is not focused on by lecturers, leading to issues of behaviour management of the students.

Furthermore, there is a consensus between lecturers and students in assessing the appropriateness of the ways of managing student behaviour and the level of implementation of such content by lecturers. This shows that most of the lecturers are carrying out the content that is assessed at the appropriate level in teaching practice and classroom management.

\section{REFERENCES}

Bluestein, J. (2008). The win-win classroom: A fresh and positive look at classroom management. Thousand Oaks, CA: Corwin Press.

Boynton, M., \& Boynton, C. (2007). The educator's guide to preventing and solving discipline problems. Alexandria, VA: Association for Supervision and Curriculum Development. Retrieved from: https://eric.ed.gov/?id=ED509054.

Burke, K. (2008). Developing cooperation, self-discipline, and responsibility in the classroom. Thousand Oaks, CA: Corwin Press.

Clandfield, L., \& Prodromou, L. (2007). Dealing with difficulties: Solutions, strategies and suggestions for successful teaching. Surrey, England: Delta Publishing.

Curwin, R. L., Mendler, A. N., \& Mendler, B. D. (2008). Discipline with dignity: New challenges, new solutions. Alexandria, VA: Association for Supervision and Curriculum Development.

Frederick, C. W., \& Catherine, H. M. (2007). Not in my classroom: A teacher's guide to effective classroom management. Avon, MA: Adams Media.

Gossen, D. C. (2006). It's all about we: Teacher workbook. Saskatoon, SK: Chelsom Consultants.

In, S. S., \& Jae, Y. C. (2009). Class size and student achievements in the United States: A meta-analysis. KEDI Journal of Educational Policy, 6(2), 3-19.

Kohn, A. (2006). Beyond discipline: From compliance to community. Alexandria, VA: Association for Supervision and Curriculum Development.

Ministry of Education and Training. (2008), Renovating classroom management measures with positive disciplinary education measures. Vietnam: Vietnam Education Publishing House.

Nash, R. (2009). The active teacher: Practical strategies for maximizing teacher effectiveness. Thousand Oaks, CA: Corwin Press.

National Assembly of the Socialist Republic of Vietnam (2015). Higher education law in 2012. Amendment and supplement in 2014. Hanoi: National Political Publishing House. 


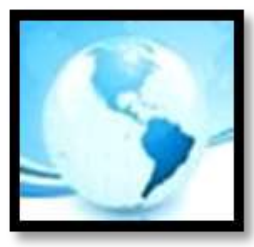

\section{MALAYSIAN ONLINE JOURNAL OF EDUCATIONAL MANAGEMENT (MOJEM)}

Nguyen, X. H. (2009). Managing schools and classes for special needs children. Vietnam: Vietnam Education Publishing House.

Page, M. L. (2008). You can't teach until everyone is listening: 6 simple steps to preventing disorder, disruption, and general mayhem. Thousand Oaks, CA: Corwin Press.

Payne, R. K. (2006). Working with students: Discipline strategies for the classroom. Highlands, TX: aha! Process, Inc.

Robert, J. M., Jana, S. M., \& Debra, P. (2013). Effective classroom management. Vietnam: Vietnam Education Publisher House.

Sapon-Shevin, M. (2010). Because we can change the world: A practical guide to building cooperative, inclusive classroom communities. Thousand Oaks, CA: Corwin Press.

Tang, T. M. (2014). New requirements of lecturers in the current period. Journal of Science and Technology University of Da Nang, 8 (81), 8-11.

Tate, M. L. (2007). Shouting won't grow dendrites: 20 techniques for managing a brain-compatible classroom. Thousand Oaks, CA: Corwin Press. 